\title{
IN-VITRO EFFICACY OF VERENDA (Ricinus communis) LEAVES EXTRACT AGAINST TICKS IN CATTLE
}

\author{
S. Islam ${ }^{1}$, S.Talukder ${ }^{1}$, J. Ferdous ${ }^{1}$, M. M. Hasan ${ }^{1}$, Y. A. Sarker ${ }^{1}$, S. Sachi ${ }^{1}$, M. A. Alim ${ }^{2}$ and M. H. \\ Sikder $^{1 *}$ \\ ${ }^{1}$ Department of Pharmacology, ${ }^{2}$ Department of Parasitology, Faculty of Veterinary Science, Bangladesh \\ Agricultural University, Mymensingh-2202, Bangladesh
}

\begin{abstract}
Tick infestation is commonly found in every commercial cattle farm and domestically reared cattle. Farm generally used acaricides to treat tick infestation; however finding new, cheap and alternative source of acaricides is a prime concern. Here, we investigated the in-vitro efficacy of verenda (Ricinus communis) leaves extracts to treat tick infestation. We prepared aqueous, methanolic and ethanolic extract of verenda leaves to apply on ticks. A total of 90 ticks (both hard ticks and soft ticks) was collected from cattle in local area of Mymensingh region and divided into 3 treatment groups: A (aqueous), B (ethanol), C (methanol) and D (control). All groups were sub-divided into 3 sub-groups on the basis of concentration of 1\%, $2 \%$ and $3 \%$ treatments. Ticks were treated with different concentration of extract and observation of tick was performed 12, 24 and 36 hours interval. The whole experiment was repeated thrice. Our data suggests 3\% methanolic extract confer highest efficacy against ticks and verenda leaves extract could be used alternatively as acaricides.
\end{abstract}

Keywords: Ricinus communis, acaricidal activities, tick, plant extract

\section{INTRODUCTION}

The livestock sector of Bangladesh that contributes 15\% of GDP is being faced a number of obstacles including ectoparasites infestation. Among ectoparasites, ticks (Boophilus microplus) are most common. Ticks and ticks born disease causes severe economic loss in this sector leading to retarded growth, loss of weight, decreased milk and meat production and vector to other pathogens. Chemical acaricides, vaccination, biological control by pathogens or predators, pheromone- assisted control, host resistance and botanical acaricides are the various approaches for the controlling of ticks (Benelli et al., 2016). But there is urgent demand to search for alternative control strategies with the principles of sustainable agriculture as development of resistance against several acaricides has been reported (Singh et al., 2014; Jyoti et al., 2015).So, the investigation of alternative and sustainable treatment against tick from the plant extract is the demand of time(Borges et al., 2011).Suitable alternative for synthetic acaricides is botanical acaricides with low toxicity and rapid biodegradation as well as prevention of development of resistance against active substances due to various mechanisms of action (Singh $e t$ al., 2015).

For these reasons, many studies of recent decade have paid the focus on the product of plant origins with biocidal activity for the pest control programs (Regnault-Roger and Philoge'ne, 2008). Ricinus communis is a plant that grows in tropics and warm temperature regions of the world. It possesses many medicinal activities including acaricidal effect. The acaricidal effect of verenda has also been studied in many parts of the world such as in Bangalore, California, Egypt (Adbel-Shafy and Zayed, 2002), Mexico (Muro et al., 2003), Australia and Namibia (Kayaa, 2000). But the acaricidal effects of verenda plant have not yet been studied in Bangladesh. This research work has been designed to develop a simple protocol for in-vitro screening and efficacy studies of verenda leaves having acaricidal efficacy.

\section{MATERIALS AND METHODS}

Study area

The experimental study was conducted in the laboratory of department of pharmacology, Bangladesh Agricultural University (BAU), Bangladesh. The study was conducted from January 2016 to June 2016 to evaluate in-vitro efficacy of verenda leaves extract against ticks.

*Corresponding e-mail address: drmsikder@bau.edu.bd

Copyright (C) 2018 Bangladesh Society for Veterinary Medicine

All rights reserved 0415/2018 


\section{Islam and others}

\section{Study plant collection and identification}

Verenda was collected from the surrounding area of Bangladesh Agricultural University (BAU). Five plants were identified and verified according to its physical characteristics by the Department of Crop Botany, BAU.

\section{Plant preparation and extraction}

Plant extraction of $R$. communis leaf was conducted by the help of soxhlet (Kumar et al., 2013) 12 cycles or till the solvent in the siphon tube of an extractor became colorless (Kumar et al., 2011). After washing the plant leaves were cut into small pieces, spread out on paper sheets, dried in shaded area at room temperature for one weeks and finely dried plant materials was crushed using a pestle and mortar to provide a greater surface area. Following this, the solvent ( $80 \mathrm{ml}$ of ethanol, methanol or water) was added to a round bottom flask, which was attached to a soxhlet extractor. The crushed plant materials were loaded into the thimble and placed inside the soxhlet extractor. The condensate was dripped into the reservoir. The process runs for a total of 16 hours. Once the process had finished, extracted plant material were in the beaker.

\section{Preparation of stock solution}

Each of the samples was categorized as 1,2 and 3 percent concentration according to petri dish size and number of ticks. We measured $0.15 \mathrm{gm}$ extract for $1 \%, 0.3 \mathrm{gm}$ extract for $2 \%$ and $0.45 \mathrm{gm}$ extract for $3 \%$ concentration. $15 \mathrm{ml}$ of distilled water was added and then mixed thoroughly by the help of orbital shaker.

\section{Collection, transportation and identification of tick}

Ticks were collected from naturally infested cattle grazed at the field of BAU. Freshly collected ticks were transported in plastic cups covered by cotton net gauze to the laboratory. Species identification was performed based on morphological identification keys given by James (2013), BAU. Ticks from naturally infested cattle, were identified by the department of parasitology according to (Walker et al., 2007).

\section{In-vitro acaricidal efficacy test}

Ticks were dipped in the respective dilutions of extracts and control solutions for 2 min of exposure. After immersion, the ticks were recovered from tube and dried with filter paper and placed in separate petri dishes (Zaman et al., 2012). $15 \mathrm{ml}$ of concentration was taken for each petri dish and for each concentration of methanolic, ethanolic and aqueous extract i.e. for $1 \%, 2 \%$ and $3 \%$ concentration. Ten adult ticks was placed in each petri dish. Cotton was soaked with same concentration was applied to the petri dish to prevent desiccation. In case of positive control we used $1 \%$ ivermectin pour on and distilled water as negative control. After incubation at $30^{\circ} \mathrm{C}$ with $80 \%$ relative humidity, death of ticks was recorded at 12 hours interval. The viability of ticks was checked regularly with a blunt needle and ticks were recorded as dead if no reaction was shown. All the experiment was then repeated thrice.

The percentage mortality was calculated by the formula previously used by Krishnaveni and Venkatalakshmi (2014) as follows:

$$
\text { Mortality } \%=\frac{\text { Nodead ticks }}{\text { Totalnumberof ticks }}
$$

\section{Statistical analysis}

Collected raw data were stored in Microsoft Excel database system used for data management. SPSS windows version IBM 20 was used for data analysis. Results of the study were expressed as a mean of mortality percentage \pm standard error (Mean $\pm \mathrm{SE}$ ). Statistical significance was determined by one way analysis of variance (ANOVA) with multiple comparison tests (Post Hoc/Turkey's test/HSD) to compare parameter within and between groups. All significant levels set at $\mathrm{P}<0.05$.

\section{RESULTS}

\section{Efficacy of $R$. communis as acaricide}

In vitro acaricidal effect of $R$. communis was studied in different preparation (aqueous ethanol and methanolic extract at various concentrations $1 \%, 2 \%$ and $3 \%$ ) and in different time intervals. The outcome of treatment with tick status, solvent types and concentrations are shown in Table 1 and chi-square values between different groups are shown in Table 2. 
After 12 hours of interval, the highest acaricidal efficacy was shown by $2 \%$ methanolic extract. After 24 hours, $3 \%$ methanolic extract have shown the most acaricidal efficacy. After 36 hours interval, about $90 \%$ death was obtained in $3 \%$ aqueous, both in $2 \%$ and $3 \%$ ethanolic extract group and $2 \%$ methanolic extract group. However, the highest efficacy was shown (100\%) was obtained in $3 \%$ methanolic extract group. In positive control group, all tick died within 2 hours of treatment and in negative control group, not a single tick died even on the $4^{\text {th }}$ day of treatment. The graphical comparisons are shown in Figure 1.

Table 1. Tick status regarding time elapse, solvent types and concentrations

\begin{tabular}{|c|c|c|c|c|c|}
\hline \multirow[t]{3}{*}{ Time elapsed (hr.) } & \multirow{2}{*}{\multicolumn{2}{|c|}{ Status of Tick for }} & \multicolumn{3}{|c|}{ Concentration } \\
\hline & & & $1 \%$ & $2 \%$ & $3 \%$ \\
\hline & \multirow[t]{2}{*}{ Aqueous } & Dead Count & $1^{\mathrm{a}}$ & $5^{\mathrm{a}}$ & $4^{\mathrm{a}}$ \\
\hline \multirow{8}{*}{12} & & Percent (\%) & 3.3 & 16.7 & 13.3 \\
\hline & \multirow[t]{2}{*}{ Ethanolic } & Dead Count & $15^{\mathrm{a}}$ & $17^{\mathrm{a}}$ & $16^{\mathrm{a}}$ \\
\hline & & Percent (\%) & 50 & 56.7 & 53.3 \\
\hline & \multirow[t]{2}{*}{ Methanolic } & Dead Count & $16^{\mathrm{a}}$ & $20^{\mathrm{a}}$ & $20^{\mathrm{a}}$ \\
\hline & & Percent (\%) & 53.3 & 66.7 & 66.6 \\
\hline & \multirow[t]{2}{*}{ Aqueous } & Dead Count & $10^{\mathrm{a}}$ & $17^{\mathrm{a}}$ & $14^{\mathrm{a}}$ \\
\hline & & Percent $(\%)$ & 33.3 & 56.7 & 46.7 \\
\hline & \multirow[t]{2}{*}{ Ethanolic } & Dead Count & $18^{\mathrm{a}}$ & $22^{a}$ & $22^{\mathrm{a}}$ \\
\hline \multirow[t]{5}{*}{24} & & Percent $(\%)$ & 60 & 73.3 & 73.3 \\
\hline & \multirow[t]{2}{*}{ Methanolic } & Dead Count & $21^{\mathrm{a}}$ & $24^{\mathrm{a}}$ & $27^{\mathrm{a}}$ \\
\hline & & Percent $(\%)$ & 70 & 80 & 90 \\
\hline & \multirow[t]{2}{*}{ Aqueous } & Dead Count & $20^{\mathrm{a}}$ & $19^{\mathrm{a}}$ & $27^{\mathrm{b}}$ \\
\hline & & Percent $(\%)$ & 66.7 & 63.3 & 90 \\
\hline \multirow[t]{4}{*}{36} & \multirow[t]{2}{*}{ Ethanolic } & Dead Count & $23^{\mathrm{a}}$ & $28^{\mathrm{a}}$ & $27^{\mathrm{a}}$ \\
\hline & & Percent (\%) & 76.7 & 93.3 & 90 \\
\hline & \multirow[t]{2}{*}{ Methanolic } & Dead Count & $27^{\mathrm{a}}$ & $28^{a}$ & $30^{\mathrm{a}}$ \\
\hline & & Percent (\%) & 90 & 93.3 & 100 \\
\hline
\end{tabular}

*a No significant variation among each concentration group

Table 2. Chi square (Pearson Chi-Square) value among Extract concentration

\begin{tabular}{lccc}
\hline Time elapsed (hr) & Concentration & Value & P value \\
\hline \multirow{3}{*}{12} & $1 \%$ & $20.463^{\mathrm{b}}$ & .000 \\
& $2 \%$ & $16.875^{\mathrm{c}}$ & .000 \\
& $3 \%$ & $18.720^{\mathrm{d}}$ & .000 \\
24 & $1 \%$ & $8.690^{\mathrm{b}}$ & .013 \\
& $2 \%$ & $4.126^{\mathrm{c}}$ & .127 \\
36 & $3 \%$ & $13.650^{\mathrm{c}}$ & .001 \\
\hline \multirow{2}{*}{36} & $1 \%$ & $4.757^{\mathrm{b}}$ & .093 \\
& $2 \%$ & $12.96^{\mathrm{c}}$ & .002 \\
\hline
\end{tabular}




\section{Islam and others}

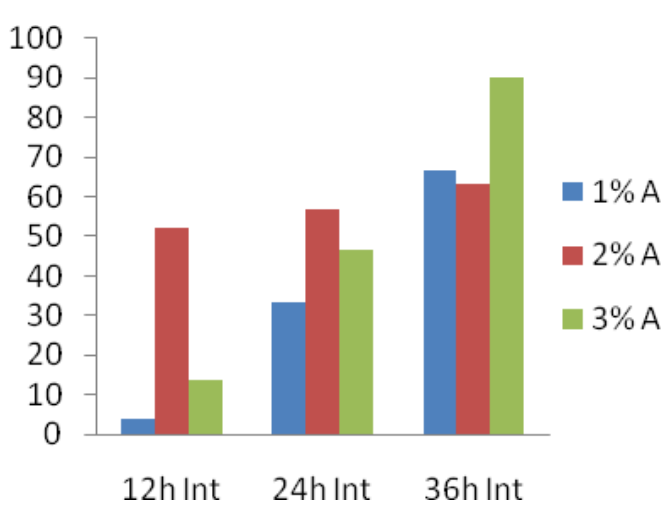

(a)

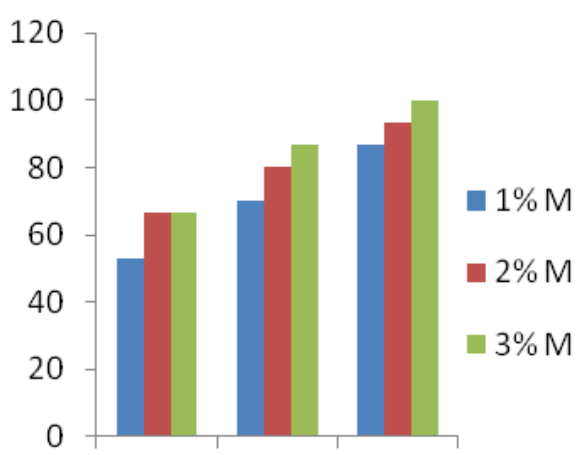

$12 \mathrm{~h}$ Int $24 \mathrm{~h}$ Int $36 \mathrm{~h} \operatorname{lnt}$

(b)

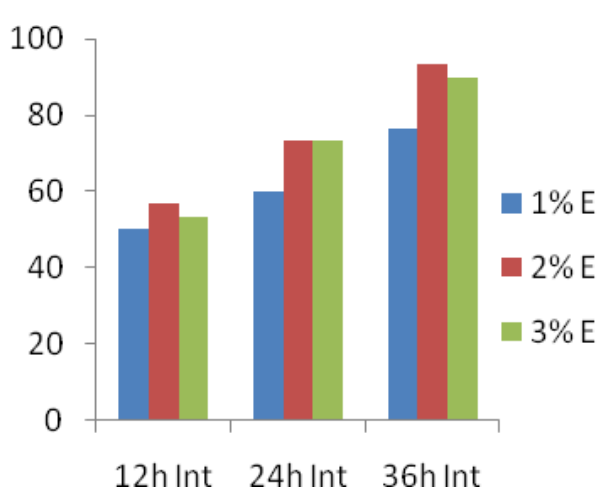

(c)

Figure 1. Acaricidal activity of R.communis plant extract. a) Efficacy of aqueous extract, b) Efficacy of ethanolic extract, c) Efficacy of methanolic extract. Here, $x$-axis indicates percentage of death ticks using extract whereas $y$-axis indicates time interval when different concentration of extract has been used.

\section{DISCUSSION}

The use of acaricidal chemicals is the empirical treatment of tick control. But due to increase development of parasitic resistance these chemicals are becoming ineffective day by day. So, it is high time to find out the new herbal solution to control these parasites as they are safe, low cost bearing, less residual effect, avoidable environmental damage (Chagas et al., 2003).In our study methanolic extract showed the highest efficacy (100\% in $36 \mathrm{hrs}$. with $3 \%$ conc.) followed by the ethanolic (93.33\% in $36 \mathrm{hrs}$. with $2 \%$ conc.) and aqueous (90\% death in 36 hrs. with $3 \%$ conc.) extract. In case of methanolic extract, $3 \%$ concentration within 12 hours (66.7) showed a good result and in 24 hours interval with $3 \%$ concentration (90\% death percentage in 24 hours) showed a better result and in 36 hours interval with $3 \%$ concentration (100\%) showed the best result. Methanolic extract of $R$. communis leaf had strong acaricidal activity (100\%) against the tick at $0.45 \mathrm{mg} / 15 \mathrm{ml}$ concentration. Kumar et al. (2013) has reported that similar methanolic extract of the plant has potent activity on Rh. decoloratus even at lower concentrations. It can be noted that methanolic $3 \%$ extract showed best result but $2 \%$ methanolic extract is cost effective. Whereas, Rahman (2002), found that ethanol extract showed higher efficacy against parasites. Probably, most of the active ingredients of verenda leaves are soluble in methanol and ethanol showing the higher efficacy against adult ticks than the other preparations. 
Efficacy of verenda leaves extract against ticks in cattle

Fernando et al. (2008) reported that ethanolic extracts Magonia pubescens St. Hil (Sapindaceae) showed no signification larvicidal activity (90-100\%) against B. microplus. In our study, ethanolic extract shows comparatively less efficacy than methanolic extract (90\% death in 36 hrs with $3 \%$ conc.). $3 \%$ aqueous extract shows $90 \%$ tick mortality after 36 hours interval; it could be the best cost-effective option. Few other studies like Abdel-Shafy et al. (2002) reported the effects of neem seed oil against eggs, nymphs and adult stages of $H$. anatolicum excavatum. They recommended that $1.6 \%$ and $3.2 \%$ concentration might be used.

It has been reported that the high toxicity of $R$. communis extracts against ticks was due to the presence of ricin in the extracts (Tounou et al., 2011) and ricin is reported as one of the most poisonous natural compounds (ElNikhely et al., 2007). Same tick mortality that was obtained by positive control group (Ivermectin) might be possible with $R$. communis leaves extract, although there is great variation in time between them. However, due to its cost effectiveness and availability in the rural area, verenda leaves could be an excellent acaricidal option.

In this case only the adult parasites were used. So, further study should be conducted to determine the acaricidal effects of verenda against other parasites and also against their various developmental stages (e.g. egg, larvae or L3) with assessment of environmental fate, species toxicity and skin toxicity of verenda plants species before they can be considered as a treatment against ticks. Besides that in vivo trial should be given in field condition and the acaricidal effects of verenda (R. communis) should be tested.

\section{ACKNOWLEDGMENT}

Authors are thankful to the Head, department of pharmacology and parasitology, faculty of veterinary science, and department of crop botany, faculty of agriculture, Bangladesh Agricultural University, Mymensingh for providing facilities to carry out the research work. This work was funded by Ministry of Science and Technology, Government's of the People Republic of Bangladesh.

\section{REFERENCE}

1. Abdel-Shafy S, Zayed AA (2002). In vitro acaricidal effect of plant extract of neem seed oil (Azadirachta indica) on egg, immature and adult stages of Hyalomma anatolicum excavatum (Ixodoidea: Ixodidae). Veterinary Parasitology 106:89-96.

2. Bekele D, Asfaw Z, Petros B, and Tekie H (2012). Ethnobotanical study of plants used for protection against insect bite and for the treatment of livestock health problems in rural areas of Akaki District, Eastern Shewa, Ethiopia Journal of Herbal Medicine 1:26.

3. Benelli G, Pavela R, Canale A and Mehlhorn H (2016). Tick repellents and acaricides of botanical origin: a green roadmap to control tick-borne diseases? Parasitology Research 115:2545-2560.doi: 10.1007/s00436-016-5095-1.

4. Borges LMF, Sousa LADD and Barbosa CDS (2011). Perspectives for the use of plant extracts to control the cattle tick Rhipicephalus (Boophilus) microplus. The Revista Brasileira de Parasitologia Veterinária 20:89-96. doi:10.1590/S1984- 29612011000200001.

5. Chagas ACS, Leite RC, Furlong J, Prates HT and Passos WM (2003) Sensibilidade do carrapato Boophilusmicroplus a solventes. Ciencia Rural 33:109-114. doi:10.1590/S0103-84782003000100017.

6. Fernando de Freitas Fernandes' Priscilla Antunes Diógenes Bessa, Edméia de Paula e Souza Freitas (2008). Evaluation of activity of the crude ethanolic extract of Magoniapubescens St. Hil (Sapindaceae) against larvae of the cattle tick Rhipicephalus (Boophilus) microplus (Canestrini, 1887) (Acari: Ixodidae). Brazilian Archives of Biology and Technology 51: 1147-1152.

7. El-Nikhely N, Helmy M, Saeed HM, Shama LA and El-Rahman ZA (2007). Ricin A chain from Ricinussanguineus: DNA sequence, structure and toxicity. Protein Journal 26:481-489. doi: 10.1007/s10930-0079088-x.

8. James P (2013). Biology of sheep lice (Bovicola ovis) pp. 1-3.www.liceboss.com.au/files/pages/notes/ Biology_of_sheep_lice_Bovicola_ovis.pdf.

9. Jyoti, Singh NK, Prerna M, Singh H and Rath SS (2015). Detection of malathion resistance in Hyalomma anatolicum anatolicum from Bathinda district, Punjab. Toxicology International 22:125-129. doi: 10.4103/09716580.172274 . 


\section{Islam and others}

10. Kayaa GP (2000). The potential for antitick plants as components of an integrated tick control strategy. Annals of the New York Academy of Sciences 916:576-582.

11. Krishnaveni S and Venkatalakshmi P (2014). Antimicrobial, larvicidal and acaricidal activities of the ethanolic extract of andrographis paniculata and carica papaya leaves. World Journal of Pharmacological Research 139:660-669.

12. Kumar Choudhury Mh, Shiferaw Y and Hussen A (2013). Toxicity of Millettiaferruginea darasana (family: Fabaceae) against the larvae and adult ticks of Amblyomma variegatum Fabricius a three-host tick in cattle. doi: 10.1007/s12639-013-0311-8.

13. Muro CEF, Cruz VC, Fernandez RM, Molina TJ, Soria CJ and Ramos PM (2003). Repellence of Boophilus microplus larvae in Stylosanthes humilis and Stylosanthes hamata plants 58:34-39.

14. Rahman M (2002). In vitro and In vivo Anthelmintic Effects of some plants Against Gastrointestinal Nematodes of Goats. M.S. Thesis. Department of Parasitology, Bangladesh Agricultural University, Mymensingh. pp. 74-77.

15. Regnault-Roger C and Philoge'ne BJ (2008). Past and current prospects for the use of botanicals and plant allele chemicals in integrated pest management. Pharmaceutical Biology 46:41-52. doi:10.1080/13880200701729794

16. Singh NK, Jyoti, Haque M, Singh H, Rath SS and Ghosh S (2014). A comparative study on cypermethrin resistance in Rhipicephalus (Boophilus) microplus and Hyalomma anatolicum from Punjab (India). Ticks Tick Borne Diseases 5:90-94. doi: 10.1016/j.ttbdis.2013.08.002.

17. Singh NK, Jyoti, Vemu B, Singh H, Prerna M, Daundkar PS, Sharma SK and Dumka VK (2015). In vitro acaricidal activity of Murraya koenigii (L.) Spreng (Rutaceae) extracts against synthetic pyrethroid resistant Rhipicephalus (Boophilus) microplus. Parasitology Research 114:1531-1539. doi: 10.1007/s00436-015-4337-y.

18. Tounou AK, Mawussi G, Amadou S, Agboka K, Gumedzoen Y, Mawuena D and Sanda K (2011). Bioinsecticidal effects of plant extracts and oil emulsions of Ricinus communis L. (Malpighiales: Euphorbiaceae) on the diamondback, Plutella xylostella L. (Lepidoptera: Plutellidae) under laboratory and semi-field conditions. Journal of Applied Bioscience 43:2899-2914.

19. Walker AR, Bouattour A, Camicas JL, Estrada-Pena A, Horak IG, Latif AA, Pegram KG and Preston PM (2007). Ticks of domestic animals in Africa: A Guide to Identification of Species. Bioscience Reports. pp 221. 